University of Nebraska - Lincoln

DigitalCommons@University of Nebraska - Lincoln

Agronomy \& Horticulture - Faculty Publications

Agronomy and Horticulture Department

May 1988

\title{
Grass Seedling Emergence, Morphology, and Establishment as Affected by Planting Depth
}

\author{
P. R. Newman \\ Research Dep., U.S. Sugar Corp., Clewiston, FL \\ Lowell E. Moser \\ University of Nebraska-Lincoln, Imoser1@unl.edu
}

Follow this and additional works at: https://digitalcommons.unl.edu/agronomyfacpub

Part of the Plant Sciences Commons

Newman, P. R. and Moser, Lowell E., "Grass Seedling Emergence, Morphology, and Establishment as Affected by Planting Depth" (1988). Agronomy \& Horticulture -- Faculty Publications. 84.

https://digitalcommons.unl.edu/agronomyfacpub/84

This Article is brought to you for free and open access by the Agronomy and Horticulture Department at DigitalCommons@University of Nebraska - Lincoln. It has been accepted for inclusion in Agronomy \& Horticulture -Faculty Publications by an authorized administrator of DigitalCommons@University of Nebraska - Lincoln. 


\title{
Grass Seedling Emergence, Morphology, and Establishment as Affected by Planting Depth
}

\author{
P. R. Newman and L. E. Moser*
}

\begin{abstract}
The seeding depth of grasses affects emergence and adventitious root development. Seedling root morphology and development should be considered when determining planting depth for forage grasses. A field study was conducted on a Kennebec silt loam (fine-silty, mixed, mesic Cumulic Hapludolls) during June to August 1985 and 1986 to investigate the effect of planting depth on seedling emergence, morphology, and establishment of smooth bromegrass (Bromus inermis Leyss.), big bluestem (Andropogon gerardii var. gerardii Vitman), indiangrass [Sorghastrum nutans (L.) Nash], and switchgrass (Panicum virgatum L.). Seeds were planted by hand to insure seeding depths of $1.5,3.0,4.5$, and $6.0 \mathrm{~cm}$. Emergence percentage decreased with increased planting depth for all grasses except switchgrass, which had similar percentages at the $1.5-$ and $3.0-\mathrm{cm}$ planting depths. Coleoptile length and seedling crown depth were positively correlated with actual planting depth in smooth bromegrass, while subcoleoptile internode length was positively correlated with actual planting depth in big bluestem, indiangrass, and switchgrass. Indiangrass differed from big bluestem and switchgrass, since its coleoptile length was positively correlated with actual planting depth. Smooth bromegrass may have the potential of increased adventitious root development due to deep placement of the seedling crown in the soil. Big bluestem, indiangrass, and switchgrass do not have the potential of increased adventitious root development as seeding depth increases, since there was no correlation of seedling crown depth with actual planting depth. Rapid increase in adventitious root number of big bluestem, indiangrass, and switchgrass was noted after three or more consecutive days of rainfall after 4 wk from planting.
\end{abstract}

Additional Index Words: Bromus inermis Leyss., Andropogon gerardii var. gerardii Vitman, Sorghastrum nutans (L.) Nash, Panicum virgatum $\mathrm{L}$., Seedling development, Subcoleoptile internode, Adventitious roots.

\section{$\mathrm{T}$} HE ADVENTITIOUS root system of an established grass plant develops from the coleoptilar node and other nodes above the seed node. Coleoptile length and the amount of internode elongation between the seed node and coleoptilar node (subcoleoptile internode elongation) determine the position of the seedling crown, which is the source of adventitious roots (Fig. 1). Since adventitious root initiation and development require high soil-surface moisture for a 3- to 5-d period (Olmsted, 1941; van der Sluijs and Hyder, 1974; Cornish, 1982), deep planting may encourage adventitious root development. Wilson and Briske (1979) demonstrated that blue grama [Bouteloua gra- cilis (H.B.K.) Lag ex Stued.] seedlings that lacked adventitious roots did not survive winter in the field.

Deep planting of forage grasses has both increased and decreased seedling emergence. Emergence percentage decreased in smooth bromegrass planted deeper than $1.3 \mathrm{~cm}$ in a silty clay loam soil (Lueck et al., 1949). 'Blackwell' switchgrass had a greater probability of emerging when planted at a depth of 5.0 to $7.5 \mathrm{~cm}$ than when planted at shallower depths in a clay loam of medium or low moisture content (Hudspeth and Taylor, 1961). Differences in the rate of utilization of seed reserves may explain why certain species emerge at greater planting depths than others (Tischler and Voigt, 1984).

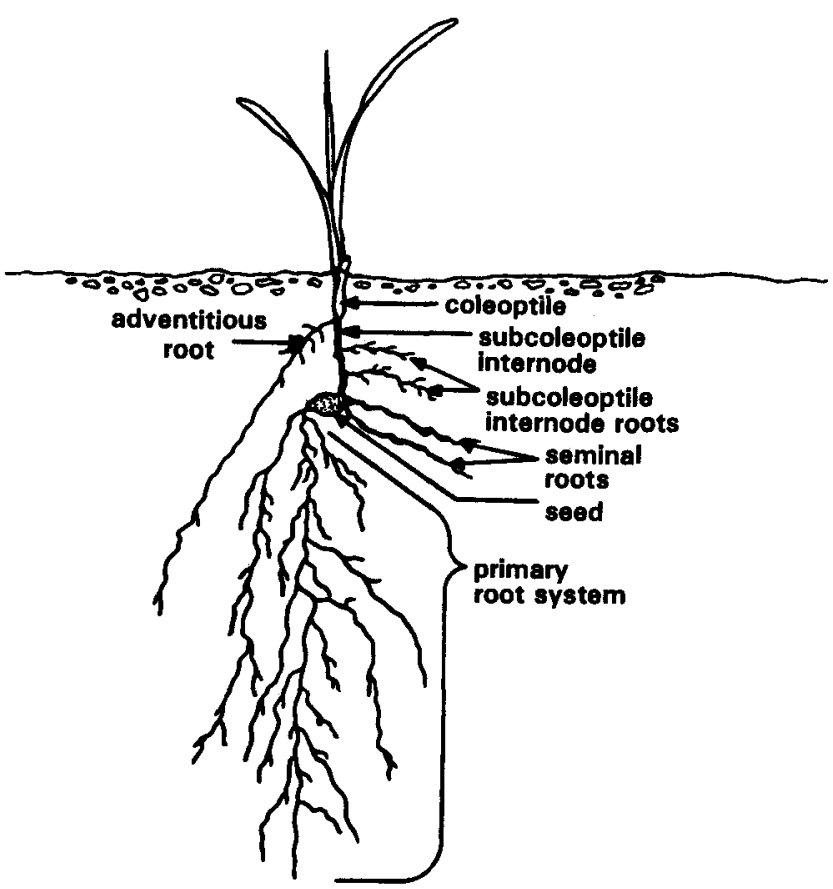

Fig. 1. Grass seedling root morphology.

P.R. Newman, Research Dep., U.S. Sugar Corp., Clewiston, FL 33440; and L.E. Moser, Dep. of Agronomy, Univ. of Nebraska, Lincoln, NE 68583. Contribution from the Dep. of Agronomy, Univ. of Nebraska. Paper no. 8246. Received 10 Feb. 1987. *Corresponding author.

Published in Agron. J. 80:383-387 (1988). 
Grass seedling morphology changes with planting depth. The subcoleoptile internode increased in length with planting depth in certain forage grasses (Hyder et al., 1971; Fulbright et al., 1985), while the internodes above the coleoptile elongated with deep planting in other grasses (Taylor and McCall, 1936). A long coleoptile that reached the soil surface permitted deep planting without subcoleoptile internode elongation, allowing the seedling crown to stay at the planting depth (Hyder et al., 1971). The planting depth recommended in arid environments is related to the combined length of the coleoptile and the subcoleoptile internode (Metcalfe and Nelson, 1985).

Grass seedling root development was shown to be less at greater planting depths (Tadmor and Cohen, 1968; Fulbright et al., 1985; Cornish, 1982). Smooth bromegrass planted at a $5.0-\mathrm{cm}$ depth had a reduced number of tillers and rhizomes, a limited root system, and a lack of adventitious roots compared to 1.3- and 2.5-cm planting depths (Lueck et al., 1949). The objectives of this research were to determine how deep a species can be planted without significantly reducing emergence percentage under field conditions, and to study the change in seedling morphology in relation to planting depth. Adventitious root development was used to determine establishment success.

\section{MATERIALS AND METHODS}

Four perennial forage grasses, smooth bromegrass, big bluestem, indiangrass, and switchgrass, were used. All seed lots, except for the 1985 big bluestem seed lot, were obtained from Dr. K. P. Vogel, Grass Geneticist, USDA-ARS. The 1985 big bluestem seed lot was obtained from Horizon Seeds, Inc., Lincoln, NE. Different seed cultivars of each grass were used in each year of the 2-yr field study. In 1985, 'Lincoln' smooth bromegrass, 'Pawnee' big bluestem, 'Holt' indiangrass, and 'Pathfinder' switchgrass were used. In 1986, 'Lancaster' smooth bromegrass, 'Kaw' big bluestem, 'Nebraska 54' indiangrass, and 'Trailblazer' switchgrass were used.

Field plots were located on the East Campus of the University of Nebraska-Lincoln. The soil at the sites for both years was Kennebec silt loam. Soil tests during the experiment showed 126 and $702 \mathrm{mg} \mathrm{kg}^{-1} \mathrm{P}$ and $\mathrm{K}$, respectively, with a pH of 7.5 in 1985 , and 67 and $279 \mathrm{mg} \mathrm{kg}^{-1} \mathrm{P}$ and $\mathrm{K}$, respectively, with a $\mathrm{pH}$ of 5.4 in 1986 . The 1985 experiment was planted on land fallow for 2 yr. The 1986 experiment had been seeded to winter wheat (Triticum aestivum L.) in the fall of 1985 and was tilled in the early spring 1986 prior to seeding the 1986 experiment.

The experimental design for both years was a split-splitplot design with five replications. Main plots ( 1 by $5 \mathrm{~m}$ ) were planting depths, and subplots were species, which were planted in single rows $5 \mathrm{~m}$ long. The sub-subplots were sampling dates in which $0.5-\mathrm{m}$ segments of the subplot rows were harvested at each date. All plots, subplots, and subsubplots were randomized within each unit. The distance between rows and main plots was $0.25 \mathrm{~m}$, and between replications, $1 \mathrm{~m}$. Seedbeds were tilled 15 to $20 \mathrm{~cm}$ deep with a rotary tiller 2 wk before planting. The 1985 plot was planted on 1 June, and the 1986 plot was planted on 2 June. Seed was planted to obtain a planting rate of 108 pure live seed per square meter. Seeding depths were obtained by making a furrow in the soil with a marked hoe, to the predetermined depths, $1.5,3.0,4.5$, and $6.0 \mathrm{~cm}$. Seed for each row was dropped uniformly into each furrow row with a precision grass-seed cone planter. The seed was covered with surrounding soil to fill the furrow and establish the predetermined planting depth. In both years, the soil was packed by rolling with a lawn roller after planting. Weeds were removed by hand within $2 \mathrm{~d}$ after emergence. Rainfall and daily mean temperature data were obtained from the $\mathrm{Na}$ tional Oceanic and Atmospheric Administration (1985-1986) weather station located at the Lincoln Municipal Airport, $8.8 \mathrm{~km}$ from the field plots.

Thirteen days from planting, the number of emerged seedlings was recorded in a $2-m$ section of each row in five replications in 1986 and in three replications in 1985. Emergence percentage was calculated by dividing the number of emerged seedlings by the number of pure live seeds planted and multiplying by 100 . Analysis of variance (SAS Institute, 1985) was performed on the emergence percentage data as a $2 \times 4 \times 4$ split-plot design in a mixed model (the year effect was considered the random factor). Appropriate $F$ tests were used to test interaction and main effects. Square root and arcsine transformations of emergence percentage data did not change the significance of the analysis of variance $(P>0.05)$; therefore, analysis of variance was performed on untransformed data. A sequence of grouped comparisons (contrasts) of planting depth on emergence percentage was made to determine the maximum planting depth. The maximum planting depth is the deepest planting depth that does not cause a significant reduction in emergence percentage from the immediately shallower depth. The contrasts followed a sequence of comparisons that compared the shallow planting depth or depths to the single, deeper planting depth. This sequence allowed a test of significance between the shallow planting depth(s) and the single, deeper planting depth.

Seedling morphology parameters recorded were coleoptile length, subcoleoptile internode length, and seedling crown depth (distance between the soil surface and coleoptilar node) (Fig. 1). These morphological parameters were recorded from seedings excavated $2 \mathrm{wk}$ after planting. The soil surface level of each seedling in the sample-row section was marked with a permanent marker. Seedlings were excavated by lifting out the soil block that held the seedlings in the planted row with a long narrow spade. The seedlings were released from the soil by gently pinching the soil. Nearly all roots were retained, although root losses were greater under dry soil conditions. The excavated seedlings were placed in a plastic bag to maintain moisture. Samples were taken to the laboratory and stored at $5^{\circ} \mathrm{C}$ until seedling morphology measurements were taken (within $3 \mathrm{~d}$ from sampling). Before morphological parameters were recorded, the seedlings were washed briefly in soapy water to remove adhering soil. Morphological parameters of three random seedlings within each replication were measured, and means were calculated for further analysis. Analysis of variance was performed in the same manner as emergence percentage data, except all five replications were used in both years. Pearson correlation coefficients (SAS Institute, 1982) were calculated to determine the effects of actual planting depth (distance between the seed and the marked soil surface on the excavated seeding) and coleoptile length, subcoleoptile internode length, and seedling crown depth of each species over all planting depths.

The number of adventitious roots was recorded from seedlings excavated at $2,3,4,6,8$, and $10 \mathrm{wk}$ from planting. Analysis of variance (SAS Institute, 1985) was performed on the adventitious root number as a $2 \times 4 \times 4 \times 6$ splitsplit-plot design in a mixed model (the year effect was considered the random factor). Appropriate $F$ tests were used to test interaction and main effects. The $4.5-$ and $6.0-\mathrm{cm}$ planting depths and smooth bromegrass were dropped from the analysis because of a large number of missing values due to limited seedling survival. 


\section{RESULTS AND DISCUSSION}

\section{Climatological Summary}

Total rainfall during the experiment in 1985 and 1986 was $351 \mathrm{~mm}$ and $276 \mathrm{~mm}$, respectively. Although total rainfall in the 1985 experiment was greater than that in 1986, 1985 had a drier establishment period because of an uneven distribution of rainfall over time (Fig. 2). In 1985, a dry period occurred between 4 and 6 wk from planting (Fig. 2). A dry period occurred between 6 and 8 wk from planting in 1986 (Fig. 2). In 1985 there were only two periods where rainfall was recorded for three or more consecutive days. They were at 1 wk from planting and just after $6 \mathrm{wk}$ from planting. In 1986 there were seven periods where rainfall was recorded for three or more consecutive days. A 9-d period of consecutive daily rainfall occurred between 4 and 6 wk from planting in 1986 .

In 1985 , the mean daily temperature gradually increased during the dry period between 4 and $6 \mathrm{wk}$ from planting. In 1986, the mean daily temperature dropped $5^{\circ} \mathrm{C}$ for approximately $4 \mathrm{~d}$ during the dry period between 6 and $8 \mathrm{wk}$ from planting.

\section{Emergence}

Contrast analyses that sequentially groups planting depths were performed on emergence percentage data to determine the maximum planting depth for each species (Table 1). In 1985, emergence percentage decreased with increased planting depth over all species except big bluestem (Table 1). Both big bluestem and indiangrass had very low emergence even at the 1.5$\mathrm{cm}$ depth. Either $1.5 \mathrm{~cm}$ was too deep or seed dormancy reduced emergence. In 1986, emergence percentage decreased with increased planting depth over all species except for switchgrass (Table 1). Switchgrass had a higher emergence percentage than other species at the $6.0-\mathrm{cm}$ planting depth in both years $\mathrm{Ta}$ ble 1 ).

For both years indiangrass had a significant difference $(P>0.01)$ in emergence percentage between the $1.5-$ and $3.0-\mathrm{cm}$ planting depths. Smooth bromegrass in 1986 and big bluestem in 1985 had significant dif-

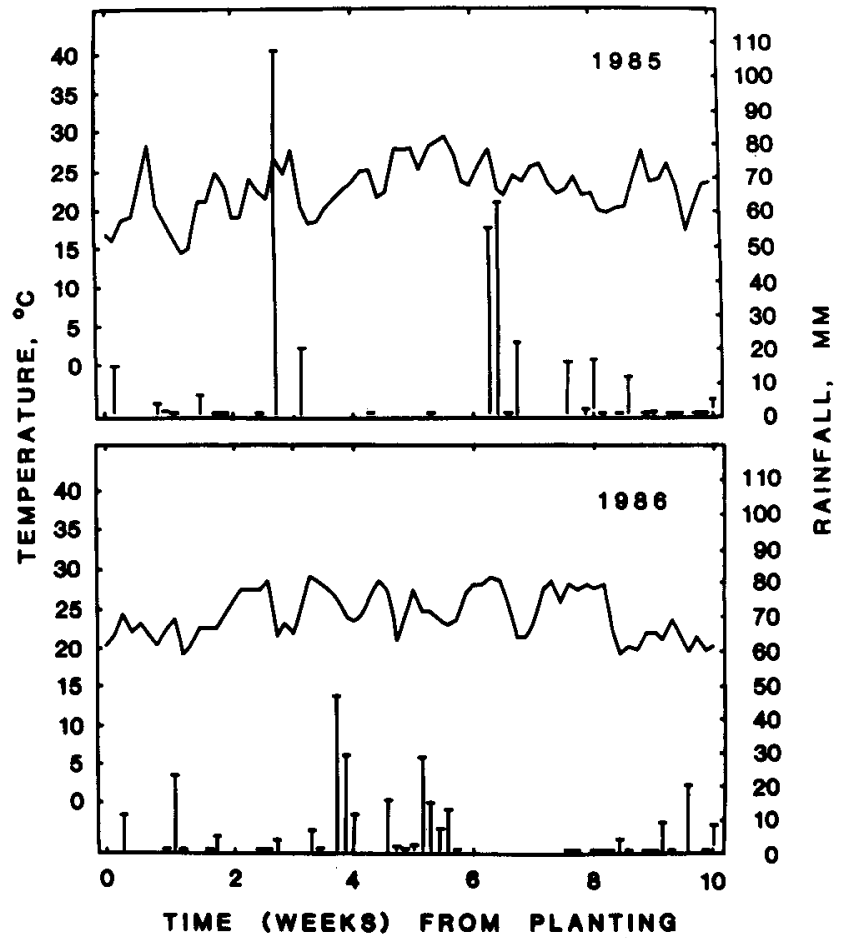

Fig. 2. Mean daily temperature and rainfall during the 1985 and 1986 seedling establishment period. Continuous line represents the mean daily temperature (daily min. + daily max./2), and vertical bars represent the daily rainfall.

ferences $(P>0.05)$ in emergence percentage between the $1.5-$ and $3.0-\mathrm{cm}$ planting depths. There was no significant difference $(P>0.05)$ in emergence percentage between the $1.5-$ and $3.0-\mathrm{cm}$ planting depths for switchgrass in both years (Table 1 ). These results suggest that the maximum planting depth is $1.5 \mathrm{~cm}$ for smooth bromegrass, big bluestem and, indiangrass. Switchgrass should be able to tolerate a $3.0-\mathrm{cm}$ planting depth on a silt loam soil.

\section{Seedling Morphology}

Smooth bromegrass had a highly significant ( $P>0.01)$ correlation of coleoptile length and seedling crown depth with actual planting depth but not with

Table 1. Means and contrast analysis of emergence percentage data taken $13 \mathrm{~d}$ after planting of the 1985 and 1986 field study of smooth bromegrass, big bluestem, indiangrass, and switchgrass at 1.5-, 3.0-, 4.5-, and 6.0-cm planting depths.

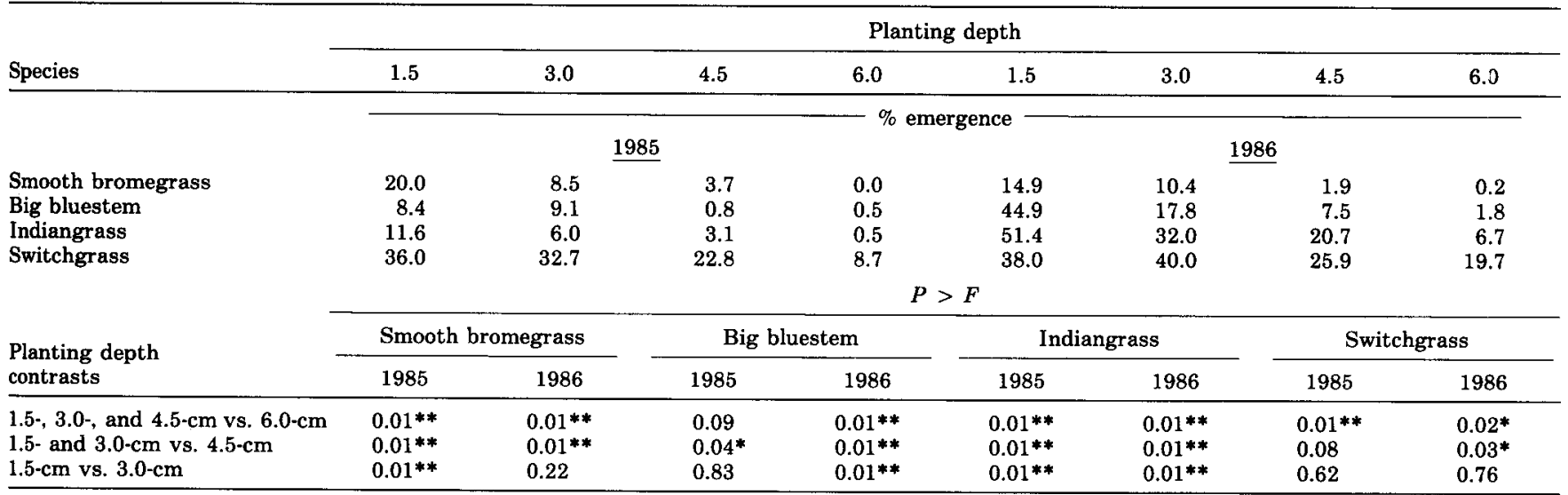

*,** Significant at the 0.05 and 0.01 probability levels, respectively. 
Table 2. Pearson correlation coefficients (SAS Institute, 1982) of coleoptile length, subcoleoptile internode length, and seedling crown depth with actual planting depth of smooth bromegrass, big bluestem, indiangrass, and switchgrass in the 1985 and 1986 field study.

Actual planting depth

\begin{tabular}{|c|c|c|c|c|c|c|c|c|}
\hline & \multicolumn{2}{|c|}{ Smooth bromegrass } & \multicolumn{2}{|c|}{ Big bluestem } & \multicolumn{2}{|c|}{ Indiangrass } & \multicolumn{2}{|c|}{ Switchgrass } \\
\hline & 1985 & 1986 & 1985 & 1986 & 1985 & 1986 & 1985 & 1986 \\
\hline Coleoptile length & $0.87^{* *}$ & $0.90^{* *}$ & -0.13 & 0.11 & $0.71 * *$ & $0.55^{*}$ & 0.21 & 0.44 \\
\hline Subcoleoptile internode length & 0.19 & 0.00 & $0.96 * *$ & $0.95^{* *}$ & $0.97 * *$ & $0.96^{* *}$ & $0.97^{* *}$ & $0.98^{* *}$ \\
\hline Seedling crown depth & $0.99^{* *}$ & $1.00^{* *}$ & $0.61 *$ & 0.30 & 0.20 & 0.29 & -0.16 & 0.06 \\
\hline
\end{tabular}

*,** Significant at the 0.05 and 0.01 probability levels, respectively.

subcoleoptile internode length in both years (Table 2). Occasionally, the internode above the coleoptilar node in smooth bromegrass elongated to form a seedling crown above the coleoptilar node. Big bluestem, indiangrass, and switchgrass had a highly significant correlation $(P>0.01)$ of subcoleoptile internode length with actual planting depth in both years (Table 2 ). Indiangrass had a significant correlation $(P>0.05)$ of coleoptile length with actual planting depth in both years, while big bluestem and switchgrass did not (Table 2). Big bluestem and switchgrass maintained a constant coleoptile length of 7 and $5 \mathrm{~mm}$, respectively, over all planting depths. In contrast, indiangrass had a 6- to $10-\mathrm{mm}$ increase in coleoptile length with an increase in planting depth. The coleoptile length of indiangrass was affected by planting depth but not to the same extent as was that of smooth bromegrass. In both years, there was no significant correlation $(P>0.05)$ of seeding crown depth with actual planting depth in indiangrass and switchgrass, while big bluestem was significant in 1985 only (Table 2). Only smooth bromegrass consistently developed a deeper seedling crown when planted deeper. Limited elongation of the subcoleoptile internode with elongation of the coleoptile of smooth bromegrass at greater planting depths placed the seedling crown deeper in the soil. Big bluestem, indiangrass, and switchgrass placed their seedling crowns near the soil surface due to subcoleoptile internode elongation; thus, their seedling crowns were only as deep as the length of the coleoptile. These distinctions between cool- and warm- season grass seedlings are similar to those found by Hyder et al. (1971) for crested wheatgrass [Agropyron desertorum (Fisch. ex Link) Schult.] and blue grama.

\section{Adventitious Root Number}

A comparison between the $1.5-$ and $3.0-\mathrm{cm}$ planting depths for number of adventitious roots was made because of limited seedling emergence at the 4.5- and $6.0-\mathrm{cm}$ planting depths. Smooth bromegrass was not included in the analysis due to poor seedling survival at all depths. The late seeding date for cool-season grasses that exposed young seedlings to high temperatures, insect feeding, or disease, or a combination of these, may explain why smooth bromegrass seedlings did not survive well.

All mean adventitious root number values for 1985 and 1986 of big bluestem, indiangrass, and switchgrass at $2,3,4,6,8$, and 10 wk from planting were not significant $(P>0.05)$ between the $1.5-$ and $3.0-\mathrm{cm}$ planting depths, except for big bluestem at $6 \mathrm{wk}$ from planting in 1986 (Table 3 ). Since all species analyzed had subcoleoptile internode elongation, all seedling crowns were at a similar depth with similar environmental conditions. The mean adventitious root number of big bluestem, indiangrass, and switchgrass at the $1.5-$ and $3.0-\mathrm{cm}$ planting depths increased with time in both years (Table 3 ). In both years, indiangrass and switchgrass had a higher mean adventitious root number than did big bluestem during early growth (Table 3).

Table 3. Mean permanent root number and $P>F$ between the $1.5-$ and 3.0-cm planting depths of big bluestem, indiangrass, and switchgrass at $2,3,4,6,8$, and 10 wk from planting in the 1985 and 1986 field study.

\begin{tabular}{|c|c|c|c|c|c|c|c|c|}
\hline \multirow[b]{2}{*}{ Species } & \multirow[b]{2}{*}{ Year } & \multirow{2}{*}{$\begin{array}{l}\text { Planting } \\
\text { depth }\end{array}$} & \multicolumn{6}{|c|}{ Weeks from planting } \\
\hline & & & 2 & 3 & 4 & 6 & 8 & 10 \\
\hline & & $\mathrm{cm}$ & \multicolumn{6}{|c|}{ permanent root no. } \\
\hline \multirow[t]{6}{*}{ Big bluestem } & 1985 & 1.5 & 0.0 & 0.8 & 1.5 & 1.4 & 13.1 & 40.5 \\
\hline & & 3.0 & 0.0 & 0.8 & 1.4 & 1.1 & 13.1 & 48.7 \\
\hline & & $P>F$ & -. & 0.74 & 0.73 & 0.53 & 0.79 & 0.73 \\
\hline & 1986 & 1.5 & 0.0 & 0.4 & 1.4 & 6.9 & 11.5 & 45.0 \\
\hline & & 3.0 & 0.0 & 0.3 & 0.8 & 4.3 & 11.3 & 37.9 \\
\hline & & $P>F$ & -- & 0.91 & 0.10 & $0.03^{*}$ & 0.92 & 0.55 \\
\hline \multirow[t]{6}{*}{ Indiangrass } & 1985 & 1.5 & 0.0 & 1.9 & 2.9 & 2.8 & 19.4 & 29.2 \\
\hline & & 3.0 & 0.0 & 0.9 & 2.9 & 2.7 & 15.1 & 23.2 \\
\hline & & $P>F$ & -. & 0.17 & 0.99 & 0.12 & 0.39 & 0.13 \\
\hline & 1986 & 1.5 & 0.1 & 1.2 & 2.0 & 10.4 & 23.5 & 51.7 \\
\hline & & 3.0 & 0.2 & 1.2 & 2.7 & 10.4 & 31.3 & 54.6 \\
\hline & & $P>F$ & 0.75 & 0.99 & 0.19 & 0.84 & 0.11 & 0.81 \\
\hline \multirow[t]{6}{*}{ Switchgrass } & 1985 & 1.5 & 0.0 & 2.1 & 2.9 & 2.9 & 22.4 & 32.0 \\
\hline & & 3.0 & 0.0 & 2.1 & 3.0 & 2.7 & 17.0 & 30.7 \\
\hline & & $P>F$ & -- & 0.99 & 0.81 & 0.63 & 0.52 & 0.80 \\
\hline & 1986 & 1.5 & 0.1 & 1.6 & 3.3 & 7.6 & 14.7 & 38.9 \\
\hline & & 3.0 & 0.3 & 1.6 & 3.0 & 7.3 & 16.2 & 53.9 \\
\hline & & $P>F$ & 0.21 & 0.99 & 0.59 & 0.87 & 0.66 & 0.06 \\
\hline
\end{tabular}

* Significant at the 0.05 probability level. 
The number of adventitious roots increased rapidly after 6 wk from planting in 1985 (Table 3). In 1986, plants sampled $6 \mathrm{wk}$ after planting had considerably more adventitious roots than those sampled at $4 \mathrm{wk}$. At $8 \mathrm{wk}$, another large increase occurred. In 1985 , little rain occurred from about 3 to 6.5 wk after planting (Fig. 2). The soil surface was dry during this period, so adventitious roots could not develop. Beginning at 6.5 wk there was $4 \mathrm{~d}$ of rainfall (Fig. 2) that kept the soil surface moist. Adventitious root development requires 3 to $5 \mathrm{~d}$ of high soil-surface moisture (Olmsted, 1941; van der Sluijs and Hyder, 1974; Cornish, 1982). Adventitious root development occurred, which was reflected in the 8-wk sampling date. In 1986 there was a long period where the soil surface was wet from 4 to $6 \mathrm{wk}$ after planting (Fig. 2), so adventitious root development started earlier. During the first $4 \mathrm{wk}$ from planting there was little adventitious root development, even with a wet soil surface, because the seedlings were in a juvenile stage.

The establishment process of the grasses has two distinct phases; (i) seedling emergence and (ii) seedling establishment (the development of the adventitious root system). Seedling emergence, but not adventitious root development, was affected by planting depth in big bluestem, indiangrass, and switchgrass. Due to late planting and poor survival of smooth bromegrass at all depths, the effect of deeper planting depth on adventitious root production could not be determined. Subcoleoptile internode length of big bluestem, indiangrass, and switchgrass was highly correlated with actual planting depth. Therefore, seedling crown depth among these grasses had no correlation with planting depth. Deeper planting will not enhance adventitious root development in big bluestem, indiangrass, and switchgrass.

\section{REFERENCES}

Cornish, P.S. 1982. Root development in seedlings of ryegrass ( $\mathrm{Lol}$ ium perenne $\mathrm{L}$.) and phalaris (Phalaris aquatica L.) sown onto the soil surface. Aust. J. Agric. Res. 33:665-677.

Fulbright, T.E., A.M. Wilson, and E.F. Redente. 1985. Green needlegrass seedling morphology in relation to planting depth. J. Range Manage. 38:266-270.

Hudspeth, E.B., and H.M. Taylor. 1961. Factors affecting seedling emergence of 'Blackwell' switchgrass. Agron. J. 53:331-335.

Hyder, D.N., A.C. Everson, and R.E. Bement. 1971. Seedling morphology and seeding failures with blue grama. J. Range Manage. 24:287-292.

Lueck, A.G., V.G. Sprague, and R.J. Garber. 1949. The effect of a companion crop and depth of planting on the establishment of smooth bromegrass, Bromus inermis, Leyss. Agron. J. 41:137140.

Metcalfe, D.S., and C.J. Nelson. 1985. The botany of grasses and legumes. p. 52-63. In M.E. Heath et al. (ed.) Forages. 4th ed. Iowa State Univ. Press, Ames.

National Oceanic and Atmospheric Administration. 1985-1986. Climatological data: Nebraska. National Climatic Data Center, Asheville, NC.

Olmsted, C.E. 1941. Growth and development in range grasses. I. Early development of Bouteloua curtipendula in relation to water supply. Bot. Gaz. 102:499-519.

SAS Institute. 1982. SAS user's guide: Basics. 1982 ed. SAS Institute Inc., Cary, NC

. 1985. SAS user's guide: Statistics. 1985 ed. SAS Institute Inc., Cary, NC.

Tadmor, N.H., and Y. Cohen. 1968. Root elongation in the preemergence stages of Mediterranean grasses and legumes. Crop Sci. $8: 416-419$.

Taylor, J.W., and M.A. McCall. 1936. Influence of temperature and other factors on the morphology of the wheat seedling. J. Agric. Res. 52:557-568.

Tischler, C.R., and P.W. Voigt. 1984. Screening and selection to improve establishment of warm-season forage grasses in arid regions. p. 115-119. In Proc. 1984 Forage and Grassland Conf. Houston, TX. 23-26. Jan. 1984. Am. Forage and Grassland Council, Lexington, KY.

van der Sluijs, D.H., and D.N. Hyder. 1974. Growth and longevity of blue grama seedlings restricted to seminal roots. J. Range Manage. 27:117-119.

Wilson, A.M., and D.D. Briske. 1979. Seminal and adventitious root growth of blue grama seedlings on the central plains. J. Range Manage. 32:209-213. 